\title{
An Evaluation of Cyclic Loading Conditions and Computed Tomography for the Strength and Petrophysical Properties of Anhydrite Caprock
}

Rudarsko-geološko-naftni zbornik

(The Mining-Geology-Petroleum Engineering Bulletin) UDC: 55.62 .502

DOI: 10.17794/rgn.2021.4.11

Original scientific paper

\author{
Mostafa Farrokhi'; Hossein Jalalifar'; Saeed Karimi Nasab ${ }^{2}$ \\ ${ }^{1}$ Department of Petroleum Engineering, Shahid Bahonar University of Kerman, Kerman, Iran \\ ${ }^{2}$ Department of Mining Engineering, Shahid Bahonar University of Kerman, Kerman, Iran
}

\begin{abstract}
Underground gas storage (UGS) in depleted reservoirs affects caprock properties. The resemblance of Qom anhydrite outcrop with cutting obtained from a $2629 \mathrm{~m}$ depth was confirmed using X-ray diffraction (XRD) results and scanning electron microscope (SEM) tests. The anhydrite specimens unconfined compressive strength (UCS) changed under static cyclic loading conditions, and also petrophysical properties, such as porosity and permeability altered under 10, 20, and 30 cycles of loading. The magnitude of loading ranged from 30 to $43 \%$ of intact anhydrite UCS. The loading rate used for cyclic loading tests was $0.004 \mathrm{~mm} / \mathrm{s}$. The samples' UCS decreased between 3.5 to $23.9 \%$ under cyclic loading conditions. The study of specimens computed tomography (CT) imaging with porosity and permeability indicated the growth of cracks, the cracks did not initiate in all lengths of specimens, hence the incremental increase in porosity did not increase the permeability of specimens. Even being under cyclic loads, the permeability of specimens stayed lower than $10^{-15} \mathrm{~m}^{2}(\mathrm{o} .001 \mathrm{mD})$ but the trend of pressure versus time for measuring permeability shows a higher drop in pressure due to changes in permeability. The study indicated that the CT imaging results are in good accordance with petrophysical findings.
\end{abstract}

\section{Keywords:}

underground gas storage; cyclic loading; anhydrite; unconfined compressive strength; computed tomography

\section{Introduction}

Depleted reservoirs hold the highest gas in place (GIP) between different underground gas storage (UGS) facilities. Caprock integrity is one of the principal issues relating to the safety of the UGS facility. The reactivation of faults due to the alteration of UGS rock mechanical properties is another possible reason for the loss of gas (Evans and Chadwick, 2009).

Storing cycles in depleted reservoirs are mainly limited to less than two times per year (Joskow, 2012). The reservoir pressure fluctuates during these cycles (Meng et al., 2015; Meng et al., 2018), changing geomechanical properties of the reservoir formation and induced stresses affecting surrounding stratum, such as caprock (Raza et al., 2016). Caprock primarily provides a seal that traps hydrocarbon or other fluids from migrating into confining layers, so during the lifetime of the UGS facility, any symptom changing the caprock integrity should be considered (Streit and Hillis, 2004).

The cyclic loading effect on the rock properties has been widely studied, for time-lapses of milliseconds (Liu et al., 2014) to months (Wang et al., 2016); and

Corresponding author: Mostafa Farrokhi; Hossein Jalalifar mostafafarrokhi@gmail.com; jalalifar@uk.ac.ir divided into dynamic (Šancer et al., 2011; Liu and He, 2012; He et al., 2016) and static (Costin and Holcomb, 1981; Liu et al., 2014) cyclic loading conditions. Anhydrite mechanical properties not only need further research, but also behaviour under cyclic loading.

Despite the increasing amount of cyclic loading research on different rock types, such as rock salt (Fuenkajorn and Phueakphum, 2010; Liang et al., 2012; Liu et al., 2014; Wang et al., 2016; Pouya et al., 2016), granite (Rao and Ramana, 1992; Chen et al., 2011), sandstone (Šancer et al., 2011; Liu and He, 2012; Taheri et al., 2017) and shale (Guo et al., 2018), the main works on the mechanical properties of anhydrite (Robertson et al., 1958; Schwerdtner et al., 1965; Bell, 1994; Smith et al., 2009; Hangx et al., 2010; Malenda et al., 2015; Mehrgini et al., 2016; Yin and Xie, 2019; Jalalifar et al., 2021) have been restricted to the study of geomechanical properties rather than the effect of cyclic loading. Anhydrite weathering characteristics on the surface that transforms to gypsum plays an important role (Bell, 1994; Trippetta et al., 2013).

Cyclic loading divides into sinusoidal and incremental types (Liang et al., 2012; Liu et al., 2014), and thence UGS in a depleted reservoir is a sinusoidal type. Monitoring the effect of cyclic loading on rock properties includes acoustic emission (AE) (Rao and Rama- 
na, 1992; Zhang et al., 2017), unconfined compression strength (UCS) degradation (Taheri et al., 2017), cycles to fail (Chen et al., 2011; Wang et al., 2016), thin section (Müller et al., 1981; Chen et al., 2011; Trippetta et al., 2013) and computed tomography (CT) scanning study (Arns et al., 2005; Zulauf et al., 2009; Cnudde and Boone, 2013).

The effect of anhydrite cyclic loading on unconfined compressive strength (UCS) is not covered in these studies. UGS in the depleted reservoirs changes the reservoir pore pressure, indirectly affecting caprock. Anhydrite UCS reduced under three increasing loading cycles (Bell, 1994), and 16 loading cycles decreased a Young modulus (Trippetta et al., 2013). This paper mainly focuses on anhydrite specimens' mechanical and petrophysical properties alteration under cyclic loading in unconfined conditions, taking into account the increasing number of seismic activities around the UGS facility.
Micro-scale alterations of anhydrite specimens under cyclic loading conditions are confirmed by computed tomography (CT) imaging since X-ray CT provides accurate and exact morphology inside rock materials (Kou et al., 2019).

\section{Experimental procedure and tests}

The effect of pore pressure fluctuation on both petrophysical and geomechanical properties in the form of cyclic loading was investigated. Cyclic loading tests included four different cycles and three levels of loading magnitude. CT imaging was used to confirm the petrophysical property degradation results.

\subsection{Specimens}

The cyclic loading tests described herein are carried out on Qom formation anhydrite because it is the cap-

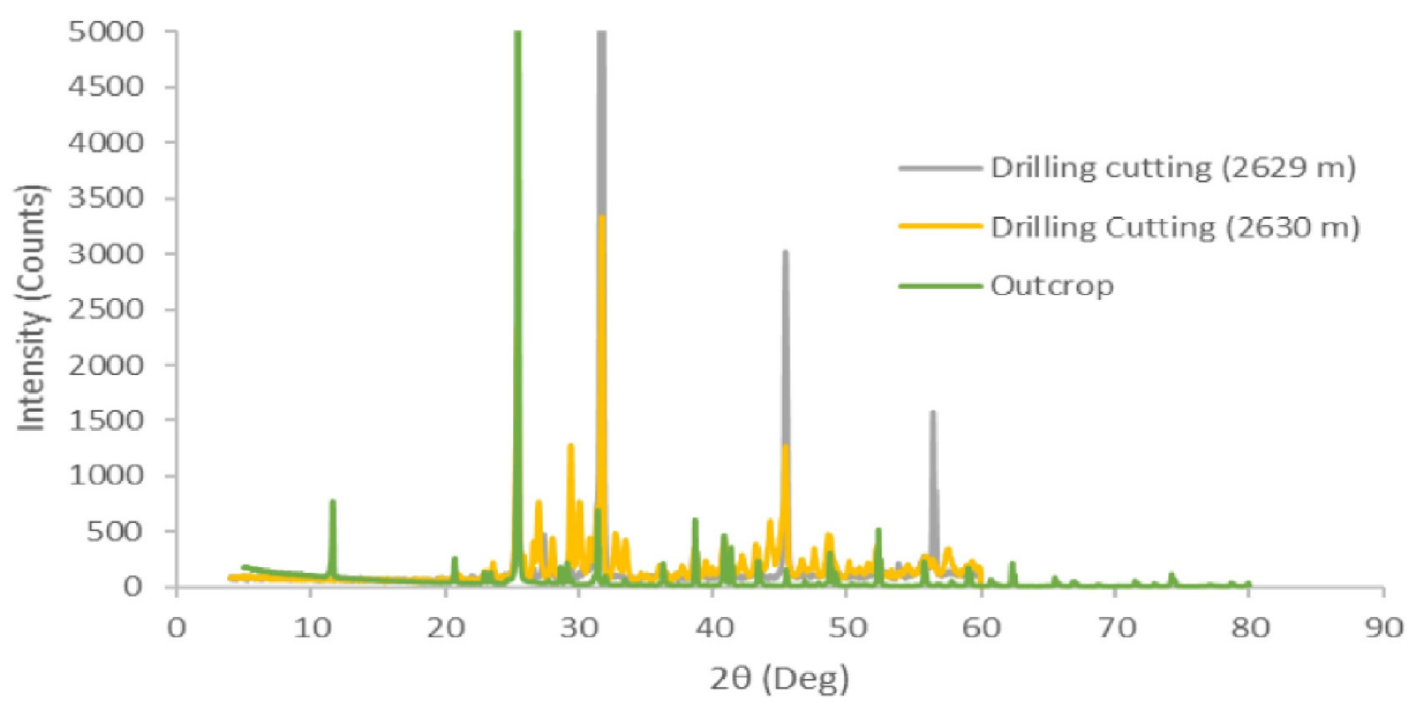

Figure 1: XRD results of Qom anhydrite cuttings and outcrop samples
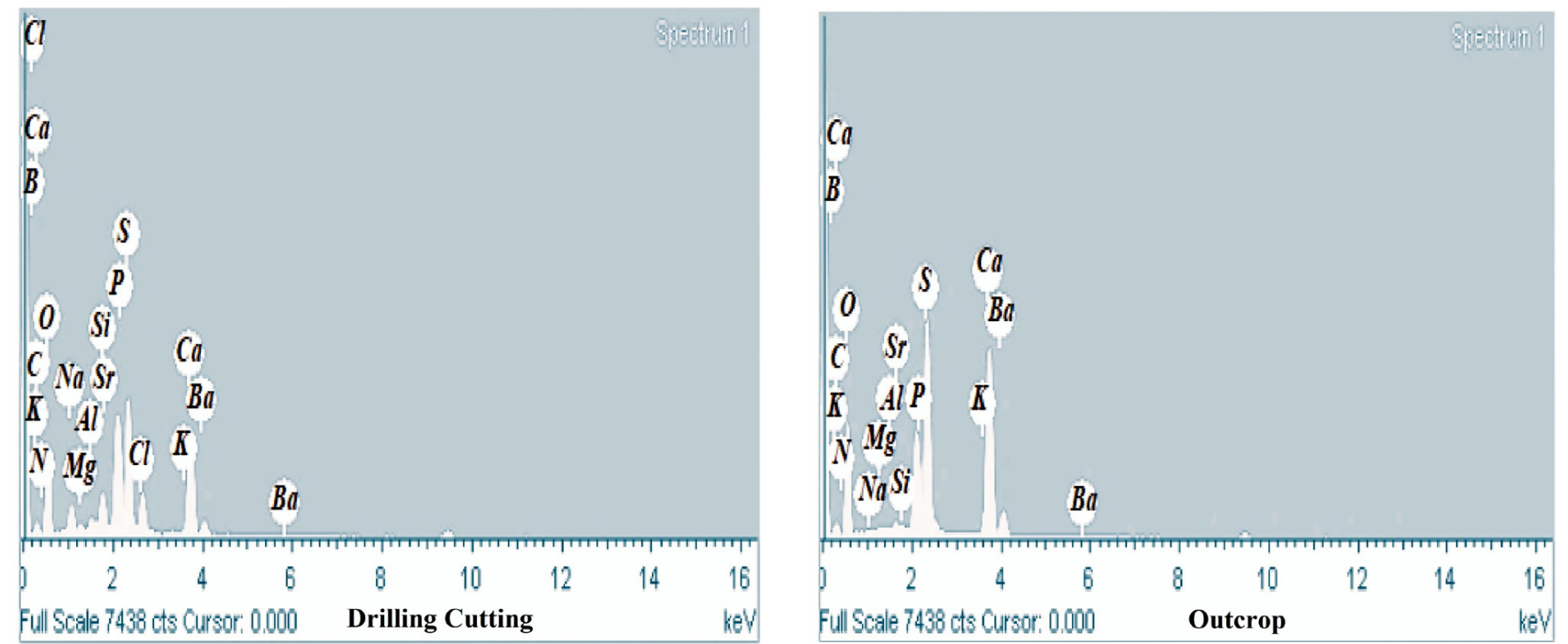

Figure 2: SEM EDAX of drilling cutting (left) and outcrop (right) 


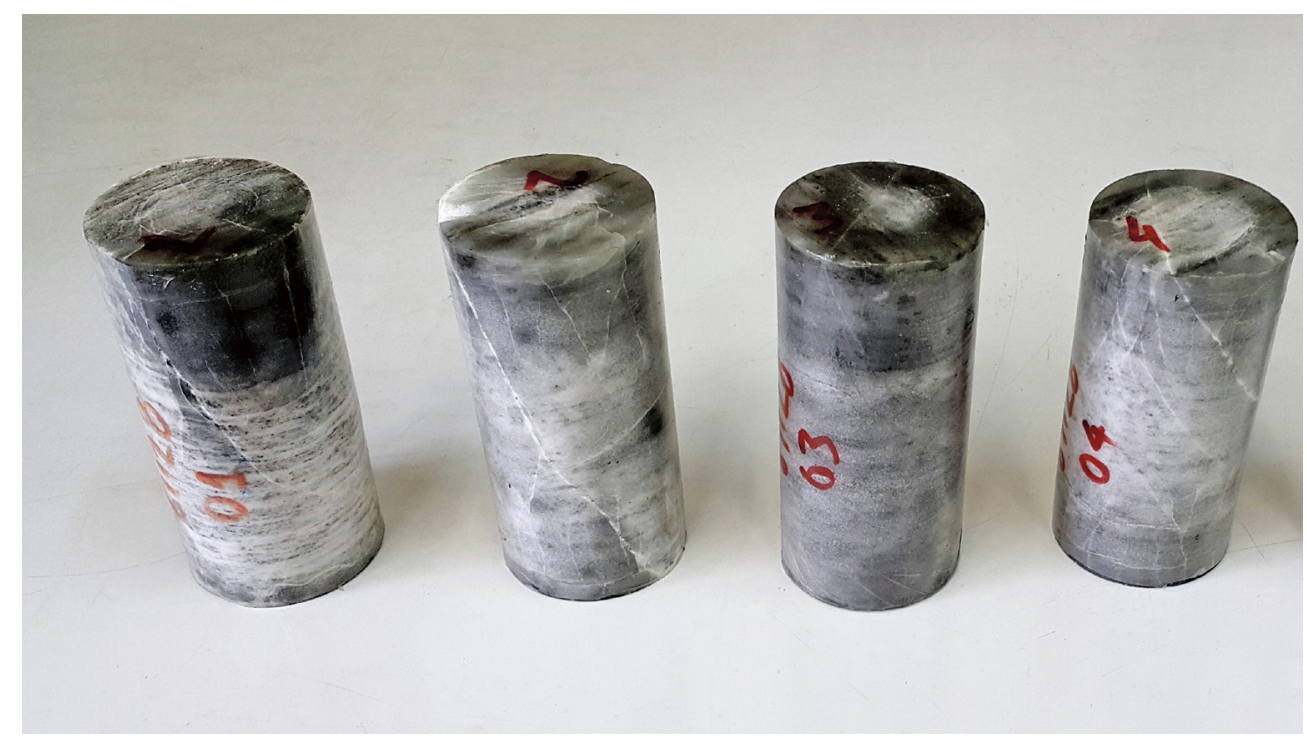

Figure 3: Anhydrite NX specimens used for triaxial tests

rock of the UGS reservoir (Reuter et al., 2009). Similar outcrop samples were gathered due to the absence of cores from caprock. Samples were prepared and cores were taken to investigate the mechanical properties of anhydrite. The resemblance of outcrop with caprock has been confirmed using X-ray diffraction (XRD by Philips PW-1800) and scanning electron microscope (SEM EDAX by Hitachi S-4200) tests on both drilling cuttings sampled from $2629 \mathrm{~m}$ and $2630 \mathrm{~m}$ depths and outcrop samples, as shown in Figure 1 and Figure 2. The obtained mechanical properties from outcrop samples were in good accordance with previous studies.

Qom anhydrite was selected since it is an impermeable rock surrounding Qom formation, making it the suitable caprock to the reservoir presented in this area which UGS would affect its properties. XRD and SEM results confirmed that Qom anhydrite mainly consisting of calcium sulfate and celestine and slightly boron minerals. The existence of halite mineral $(\mathrm{NaCl})$ in drilling cutting obtained from $2629 \mathrm{~m}$ depth could be due to overlaying evaporite sedimentary layers consisting of salt rock covering the anhydrite caprock, as shown in Figure 2.

Anhydrite sample selection from the outcrop was confirmed using the Schmidt hammer rebound (SHR) test to restrict the weathering effect on samples, previous studies reported anhydrite SHR index ranges from 30 to 43 (Bell, 1994; Shalabi et al., 2007). The density and wave velocity of the anhydrite specimens varied between 2890 and $2940 \mathrm{~kg} / \mathrm{m}^{3}$ and ranged from 5450 to $5800 \mathrm{~m} / \mathrm{s}$ respectively. Specimens used in this paper were gathered from an identical outcrop block to minimize the specimen's anomaly, anhydrite samples with similar P-wave velocities were selected for cyclic loading tests.

A set of Anhydrite NX cores (54 mm diameter) was prepared from identical anhydrite rock blocks obtained from the outcrop and was used to investigate the mechanical properties of anhydrite as shown in Figure 3. The sample preparation and testing procedure for the mechanical property of anhydrite conformed to the requirements of the international society of rock mechanics (ISRM) (Brown, 1981; Mohammadabadi et al., 2021).

The specimens were cored with a coring machine using water as the cooling agent perpendicular to the layering. A set of $38.1 \mathrm{~mm}$ (1.5-inches) diameter cores with a length to diameter ratio of 2:1 was prepared to study the alteration of anhydrite petrophysical and geomechanical properties under cyclic loading conditions. Petrophysical properties of specimens before and after cyclic loading tests were obtained using the Petro Ahoura U.S.S Perm apparatus. These samples were 3D CT imaged with 100-micron resolution before and after the cyclic loading test. The effect of cyclic loading on anhydrite UCS under the different number of cycles and loading magnitude was studied and indicated the critical magnitude of loading causing incremental damage in anhydrite specimens.

The pressure of the UGS facility fluctuates due to the Injection-Production mechanism, changing between the minimum and maximum pressure. Depleted reservoir pore pressure variation affects the condition of surrounding rocks, including impermeable formations confining the reservoir. The cyclic loading effect on evaporate rocks was mainly focused on rock salt, covering both mechanical and creep properties due to crack initiation and a reduction of mechanical properties. Anhydrite is the caprock of this carbonate reservoir and the effect of cyclic loading conditions on anhydrite needs further investigation. The static uniaxial cyclic loading tests were carried out on 18 core samples obtained from the Qom anhydrite outcrop. Anhydrite mechanical properties 
Table 1: Qom anhydrite geomechanical properties obtained from laboratory tests

\begin{tabular}{|l|l|l|l|l|l|l|l|l|}
\hline Case Study & Density & Vp & UCS & E & v & C & $\boldsymbol{\varphi}$ & TS \\
\hline Unit & $\mathrm{kg} / \mathrm{m}^{3}$ & $\mathrm{~m} / \mathrm{s}$ & $\mathrm{MPa}$ & $\mathrm{GPa}$ & - & $\mathrm{MPa}$ & $\circ$ & $\mathrm{MPa}$ \\
\hline Qom Anhydrite & 2910 & 5645 & 60 & 30 & 0.24 & 11 & 34 & 8.0 \\
\hline
\end{tabular}

Table 2: Specimens' condition used for different static cyclic loading test

\begin{tabular}{|l|c|c|c|}
\hline Samples & \multicolumn{3}{|c|}{ Number of Cycles } \\
\hline Cyclic Magnitude & 10 Times & 20 Times & 30 Times \\
\hline $18 \mathrm{MPa}$ & B3 & B40 & B2 \\
\hline $21 \mathrm{MPa}$ & B1 & B4 & B5 \\
\hline $24 \mathrm{MPa}$ & B8 & B6 & B7 \\
\hline $25 \mathrm{MPa}$ & A7 & A5 & A8 \\
\hline
\end{tabular}

such as $\mathrm{P}$-wave velocity $\left(\mathrm{V}_{\mathrm{P}}\right)$, unconfined compressive strength (UCS), young modulus (E), Poisson's ratio (v), cohesion $(C)$, friction angle $(\varphi)$, and tensile strength (TS) were obtained (see Table 1).

These properties were combined with UGS wellhead pressure history to provide an upper-stress limit for cyclic loading tests. All cyclic loading tests were performed using Azmon-50 KN electrohydraulic servo-control testing apparatus. Strain control mode with a loading rate of $0.004 \mathrm{~mm} / \mathrm{s}$ was used for UCS tests, and loading control mode was used for cyclic loading tests.

The applied axial loading cycles were sinusoidal compressive loads and the number of loading cycles divided into 10,20, and 30 times per loading level, respectively. In this paper, each loading cycle is assumed as one year of UGS operation. The maximum stress level (ratio of maximum cyclic stress to anhydrite average UCS) varied from 0.3 to 0.42 . The samples loaded up to maximum stress level, then the cyclic test performed in different amplitudes and similar frequency as shown in Table 2.

Finally, all the samples UCS obtained and the effect of cyclic loading on anhydrite specimens UCS reported. The porosity and permeability of a set of 9 specimens were measured before and after cyclic loading tests to understand the effect of fatigue resulting from cyclic loading on petrophysical properties. The PROMAX 3D D-054-C CT imaging unit with the 100-micrometer resolution was used to correlate the effect of fatigue on samples' petrophysical properties.

\section{Results}

Cyclic loading affects the specimens' macro and micro-scale properties, these effects change the mechanical and petrophysical properties of specimens subjected to a different number of cycles and loading magnitude. The intensity of specimen properties alteration increases with an increase in the number of cycles and magnitude of loading, although monitoring sonic wave travel time indicates that micro-scale changes become less sensitive to loading cycles in greater loading magnitude and hence the critical operating period for a UGC facility is the first decade.

\subsection{Anhydrite cyclic loading and mechanical property}

The experiment included three different numbers of cycles with four different maximum loading magnitudes. The number of cycles was 10, 20, and 30 for each loading magnitude, and loading varied from 0 to 18,21 , 24 , and $25 \mathrm{MPa}$ respectively. Damage evolution of rock salt under cyclic loading conditions in the range of 20 to $86 \%$ of UCS has been studied (Liu et al., 2014). Anhydrite specimens were cyclically loaded; subsequently, cyclic loading degraded anhydrite specimens UCS in different loading ranges from 30 to $42 \%$ of UCS as presented in Figure 4. Both increasing the number of loading cycles and loading magnitude reduced anhydrite UCS, the number of cycles has a lesser effect rather than the magnitude of loading on this reduction. UCS reduction due to cyclic loading ranged from 3.5 to $23.9 \%$.

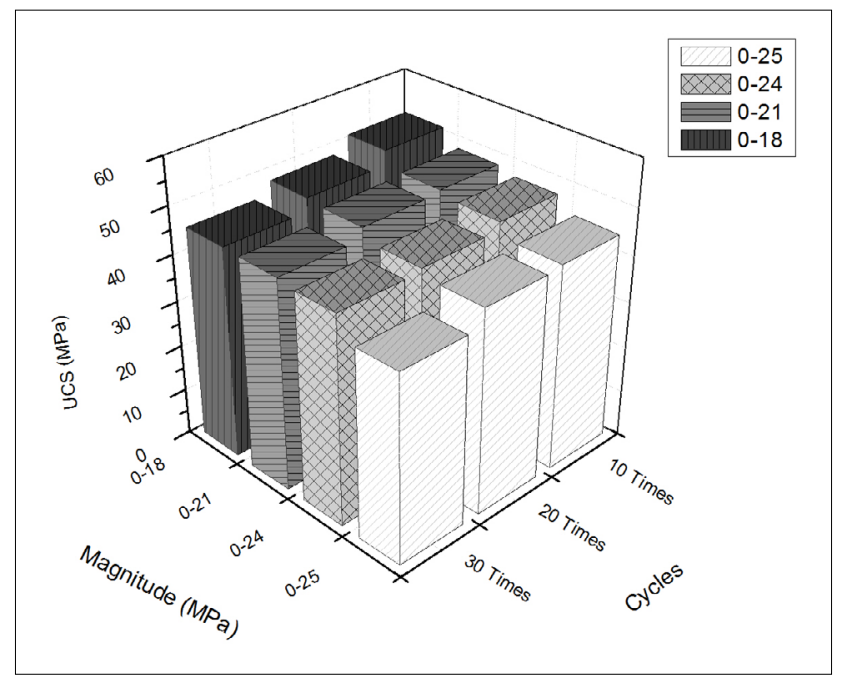

Figure 4: Static cyclic loading effect on specimens UCS

\subsection{Anhydrite cyclic loading and petrophysical properties}

Anhydrite specimen's porosity and permeability before and after cyclic loading conditions were measured using Petro Ahoura U.S.S PERM apparatus. The results as shown in Table 3 indicated a minor change in poros- 
Table 3: Cyclic loading effect on petrophysical properties of specimens

\begin{tabular}{|c|c|c|c|c|c|c|c|}
\hline \multirow[b]{2}{*}{$\begin{array}{l}\text { Cyclic } \\
\text { Load }\end{array}$} & \multirow[b]{2}{*}{ Test condition } & \multicolumn{2}{|c|}{10 Times } & \multicolumn{2}{|c|}{20 Times } & \multicolumn{2}{|c|}{30 Times } \\
\hline & & 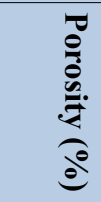 & 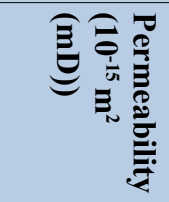 & 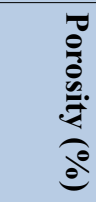 & 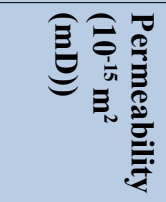 & 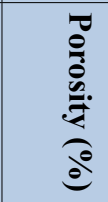 & 急全总 \\
\hline \multirow{2}{*}{$18 \mathrm{MPa}$} & Before cyclic load & 0.011 & 0.00021 & 0.010 & 0.00052 & 0.010 & 0.00012 \\
\hline & After cyclic load & 0.047 & 0.00016 & 0.024 & 0.00011 & 0.064 & 0.00009 \\
\hline \multirow{2}{*}{$21 \mathrm{MPa}$} & Before cyclic load & 0.014 & 0.00055 & 0.010 & 0.00052 & 0.002 & 0.00046 \\
\hline & After cyclic load & 0.008 & 0.00008 & 0.044 & 0.00003 & 0.006 & 0.00008 \\
\hline \multirow{2}{*}{$24 \mathrm{MPa}$} & Before cyclic load & 0.035 & 0.00066 & 0.010 & 0.000066 & 0.012 & 0.00070 \\
\hline & After cyclic load & 0.002 & 0.00007 & 0.039 & 0.000074 & 0.190 & 0.00006 \\
\hline
\end{tabular}

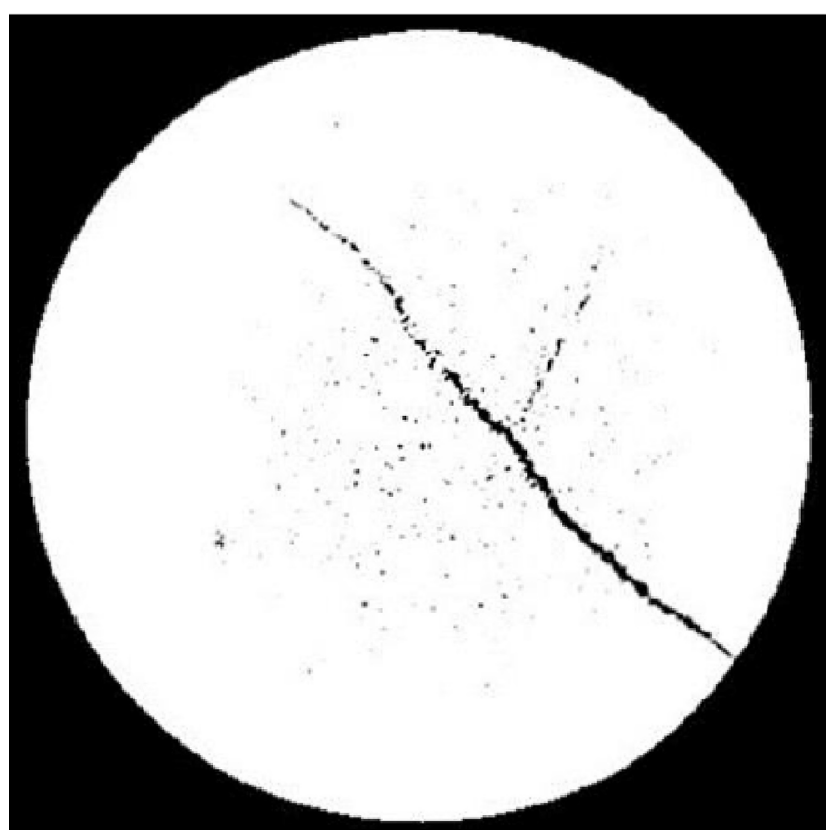

Figure 5: CT image of sample A8 after 30 times $25 \mathrm{MPa}$ magnitude cyclic loading

ity where the change in specimens' permeability was negligible, it could be due to discontinuity of created voids. Cyclic loading up to $42 \%$ UCS on specimen A8 indicated that even with an increase in specimen's permeability, the specimen stayed intact under 30 cycles of $25 \mathrm{MPa}$ loading as shown in Figure 5.

Petrophysical properties of anhydrite specimens' change as a result of the increase in the number of loading cycles, the porosity of specimens increased due to cyclic loading however permeability changes due to cyclic loading are minor or negligible. Permeability measurement indicated that an increase in permeability due to cyclic loading is less than $10^{-15} \mathrm{~m}^{2}(0.001 \mathrm{mD})$.

Figure 6 indicates the effect of cyclic loading on petrophysical properties of specimen B4, even with an increase in the specimen's porosity, the connectivity of voids leading to permeability reduces. Regarding B4

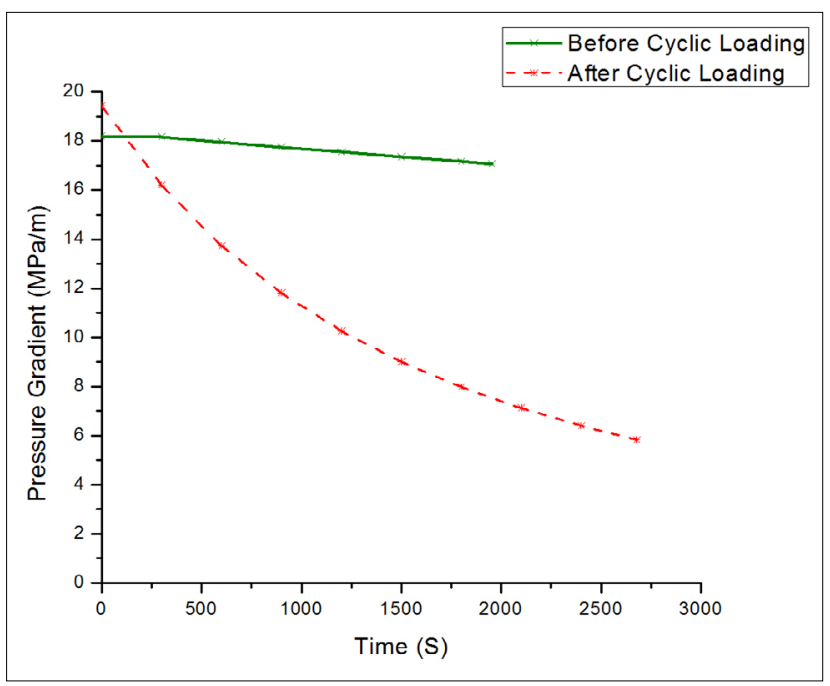

Figure 6: Specimen $\mathrm{B}_{4}$ Pressure gradient-Time graph due to 20 cycles of $21 \mathrm{MPa}$ loading magnitude (triangles and circles indicate the pressure gradient before and after loading, respectively).

results presented in Figure 7, it could be concluded that in one end of the specimen, a crack initiated while the other end shows compression due to cyclic loading. Yet the permeability in both conditions whether cyclically loaded or before loading stayed beyond $10^{-15} \mathrm{~m}^{2}(0.001$ $\mathrm{mD})$, as shown in Figure 6.

\subsection{Anhydrite CT images}

CT imaging is widely used for the study of porous media, yet this method can be used for impermeable samples (Meng et al., 2015), where monitoring CT number alteration due to experiment plays the main role in the correlation of real property and CT results (Cnudde and Boone, 2013). CT imaging shows a good convergence with the layering nature of anhydrite specimens as an evaporate rock, however, because a higher density causes a higher CT number for specimens, CT number variation due to cyclic loading conditions is 

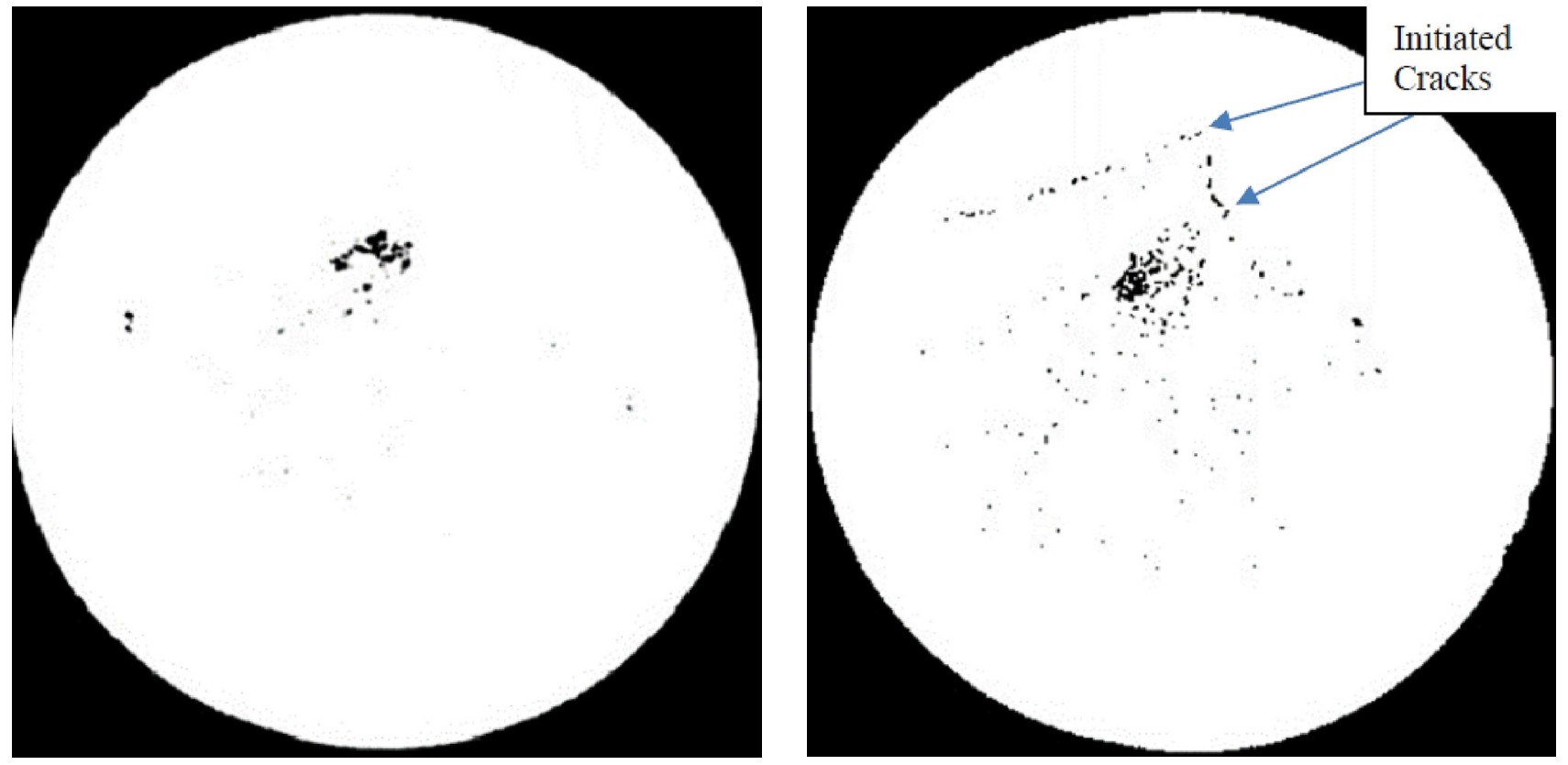

Figure 7: CT image of $\mathrm{B}_{4}$ specimen before (left) and after (right) cyclic loading

clear. Figure 7 shows a cross-section of B4 specimen CT image before and after cyclical loading, the specimen was cyclically loaded 20 times to a maximum of 21 $\mathrm{MPa}$. Crack initiation through the specimen is observed due to cyclic loading.

The B1, B3, B4, B5, B6, and B8 specimens CT numbers change before and after cyclical loading is presented in Figure 8. The CT number differentiation increased drastically with an increase in the number of cycles, which is in good agreement with the results obtained from the UCS study.

\section{Discussion}

UGS in a depleted reservoir changes the geomechanical and also petrophysical properties of both the reservoir and the caprock (Raza et al., 2016). Understanding the effect of cyclic loading resulting from the pressure fluctuating nature of UGS is essential. This paper investigated the effect of cyclic loading on the mechanical and petrophysical properties of anhydrite specimens as the main caprock of the UGS reservoir. The results have compared with other research on similar rock types.

\subsection{UCS alteration due to cyclic loading}

The study of anhydrite specimens' UCS subjected to cyclic loading indicates 3.5 to $23.9 \%$ UCS reduction depending upon the number of cycles and magnitude of loading (see Figure 9). The result was in good accordance with salt rock UCS reduction due to cyclic loading (Fuenkajorn and Phueakphum, 2010). Anhydrite UCS due to cyclic loading is more sensitive to the magnitude of loading rather than the number of cycles, the higher the magnitude of cyclic loads, the smaller the effect of the number of cycles. The observations on the effects of magnitude of loading and number of cycles on anhydrite specimens during cyclic loading have good accordance with results reported on the rock salt (Fuenkajorn and Phueakphum, 2010), sandstone (Šancer et al., 2011), shale (Guo et al., 2018) and granite specimens (Jobli et al., 2017).

The performed tests indicated an early stage increase in the magnitude of loading results in higher damage to anhydrite mechanical properties, while in posterior cycles, an increase in the magnitude of loading has a smaller effect on decreasing the specimen's UCS. The results obtained on anhydrite specimens are in good agreement with those of shale (Guo et al., 2018) and granite specimens (Jobli et al., 2017).

The study of anhydrite under cyclic loading condition based on UCS cyclic indicates that between 10 and 20 cycles, an increase in the number of cycles results in minor damage comparing to early loading stages. The reduction effect of the number of cycles at the later time is in good agreement with those reported on shale (Guo et al., 2018) and argillaceous limestone (Liang et al., 2017). The study of all cyclic loading condition scenarios showed that an increase in the amount of gas in place in the form of injection pressure needs extra care if it happens at the UGS first decade of operation, alteration of geomechanical properties after 10 cycles of loading is minor. The effect of loading magnitude of anhydrite geomechanical properties is in good correlation with salt (Liu et al., 2014; Wang et al., 2016), Brisbane tuff (Erarslan and Williams, 2012), and integrity of low-density cement ( $\mathbf{L i}$ et al., 2017) under cyclic loading. 

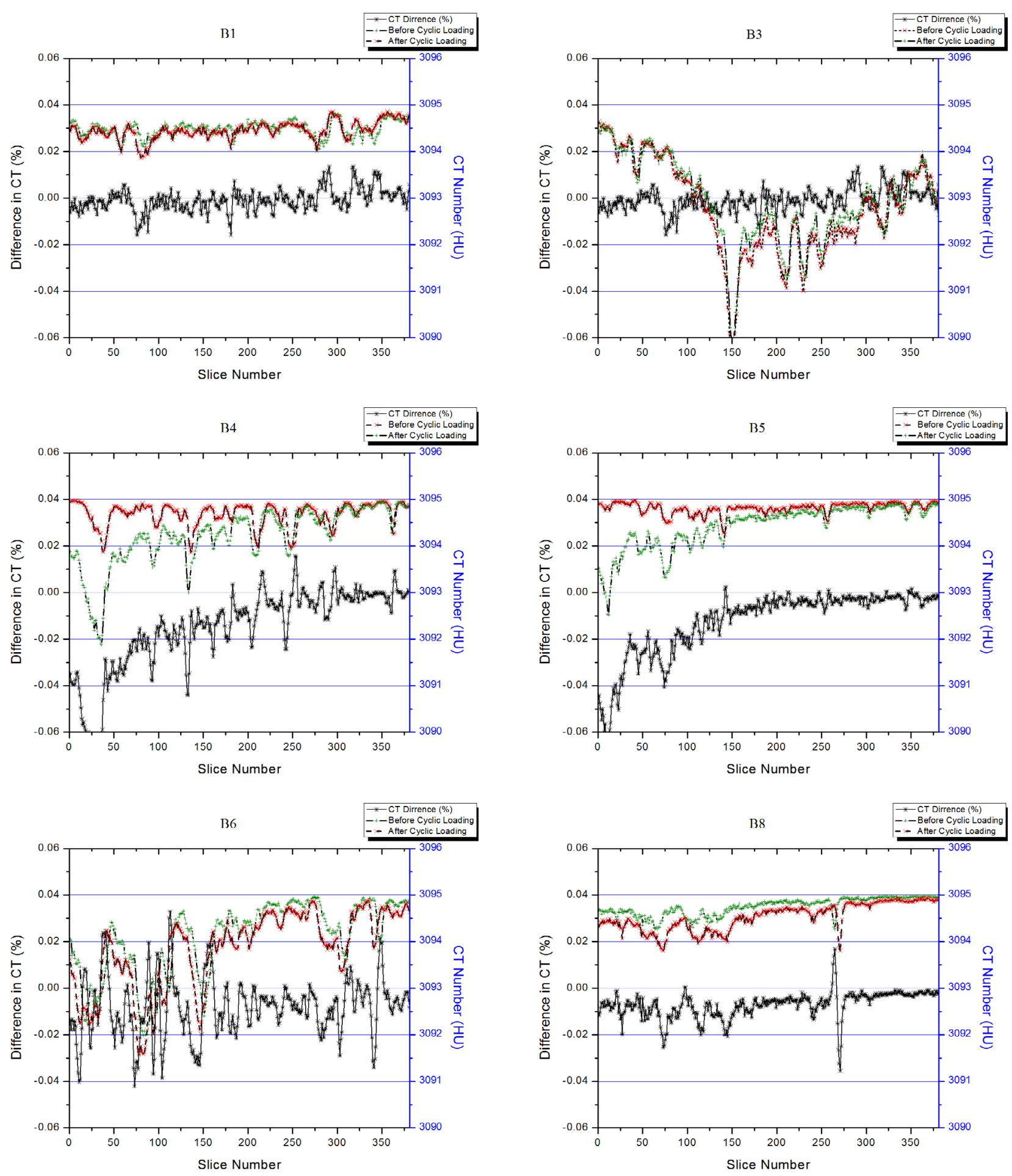

Figure 8: CT number (left axis) and percentage change in CT after loading (right axis) of specimens $\mathrm{B}_{1}, \mathrm{~B}_{3}, \mathrm{~B}_{4}, \mathrm{~B}_{5}, \mathrm{~B}_{6}$, and B8.

\subsection{Porosity and permeability reduction due to cyclic loading}

The study of anhydrite under cyclic loading conditions indicates a notable increase in the porosity of specimens in most cases, while permeability change is more dependent upon a higher number of cycles and a greater magnitude of loading (see Table 3). Likewise, the in- creasing number of cycles from 10 to 20 has changed the specimen's CT number differently (see Figure 8). Compressive cyclic loading changed the property of the specimen, as shown in Table 3 only for the loading magnitude of $18 \mathrm{MPa}$. An increase in the number of cycles reduced the porosity, but for a higher loading magnitude, the porosity of the specimen increased for all numbers of cycles. For instance, an increase in density has been ob- 


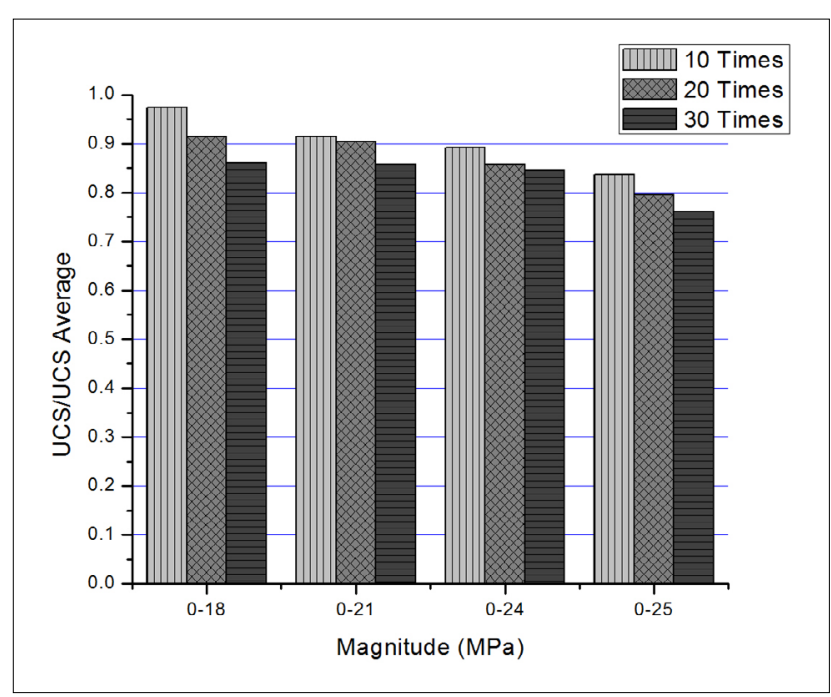

Figure 9: Cyclic loading effect on relative UCS

served in the whole length of B3 specimen under $10 \mathrm{cy}$ cles of up to $18 \mathrm{MPa}$ loadings, unlike a reduction in CT number in the length of B1 specimen has been observed under 10 cycles of $21 \mathrm{MPa}$ loading. Also, a decrease in CT number at the length of specimens due to increases in the number of cycles from 10, 20, and 30 cycles have been observed (see Figure 8). The study of CT images indicated the CT number reduction was due to crack initiation in the middle part of the specimens. This explains the lower increase in permeability of these specimens subjected to cyclic loading tests even with an increase in porosity. It can be concluded from $\mathrm{CT}$ differenced monitoring that the lower number of cycles, the lower the CT difference, and hence crack growth seems more possible comparing with crack initiation. The study of CT difference and petrophysical property changes indicated critical storage pressure that affects the caprock integrity, it dictates the storage capacity of the UGS facility.

\subsection{CT correlation with petrophysical properties}

The CT images have been used to quantify the cyclic loading effect on the specimen's density, the CT number has changed and indicated that the specimen's microscale and macroscale property changes affected density. The study of CT images indicated that crack growth is restricted to the specimen's central parts and even with the change in porosity, the scattering cracks resulted from cyclic loading did not affect specimen permeability. The study of CT images of specimens B3, B1 and B8 indicated that with an increase in the magnitude of loading at 10 times loading, an increase in the magnitude of loading lead the CT number to reduce comparing with a lower loading magnitude, and the CT number reaching a value around zero. Comparing B1, B5 and B4 CT numbers indicate that for the magnitude of $21 \mathrm{MPa}$, a loading increase in the number of cycles from 10 to 20 and 30 increases the specimens' alteration, this alteration in specimen B8 was considerable and also increased the permeability. The CT image quantifying results are in good agreement with those obtained from fatigue damage on shale (Guo et al., 2018) and salt rock (Wang et al., 2016).

\section{Conclusions}

Anhydrite geomechanical and petrophysical degradation due to cyclic loading conditions was investigated under uniaxial conditions using a servo-control testing machine under different magnitudes and intensities of loading. Specimens were gathered from Qom anhydrite outcrop and the outcrop resemblance with caprock was confirmed using XRD and SEM EDAX tests for reducing the effect of weathering on samples, and the SHR test was also used for outcrop selection.

Cyclic loading reduced the specimens' UCS, and the UCS reduction depends on the number of cycles and magnitude of loading. The specimens' petrophysical properties also changed as a result of cyclic loading, but even with the increase in porosity in most cases, permeability reduced, and the study of CT images indicated that this reduction resulted from the dissociation of produced voids. The degradation of anhydrite mechanical properties due to cyclic loading was in good accordance with salt rock, shale, sandstone, and granite. The critical cyclic loading intensity threshold was similar to salt rock and lower than shale. Anhydrite petrophysical degradation due to cyclic loading with $\mathrm{CT}$ imaging showed that even with an increase in the specimens' porosity, the change in permeability was negligible. The CT images indicated that the distribution of cracks mainly alters the specimens' porosity but the permeability stays nearly intact. The study of CT images indicated that the permeability change happens when the difference between CT numbers before and after cyclic loading becomes linear instead of sinusoidal.

\section{Acknowledgment}

The authors would like to thank Kashigar Geomechanical Research Centre (KGRC) and the staff for their great support and contribution toward the development of knowledge, it should be mentioned that fulfillment of this research relied upon data provided by Iranian Central Oil Fields Company (ICOFC) and the support from their R\&D centre which provided proper data and support.

\section{References}

Arns, Christoph H. Bauget, Fabrice, Limaye, Ajay, Sakellariou, Arthur, Senden, Timothy, Sheppard, Adrian, Sok, Robert M., Pinczewski, Val, Bakke, Stig, Berge, Lars I., Oren, Paul E., Knackstedt, Mark A. (2005): Pore scale characterization of carbonates using X-ray microtomography. Spe Journal, 10, 04, 475-484, https://doi.org/10.2118/ 90368-PA. 
Bell, FG. (1994): A survey of the engineering properties of some anhydrite and gypsum from the north and midlands of England. Engineering geology, 38, 1-2, 1-23, https:// doi.org/10.1016/0013-7952(94)90021-3.

Brown, Edwin T. (1981): Rock characterization, Testing and Monitoring: ISRM Suggested Methods, Pergamon press, 211 pages.

Chen, Youqing, Watanabe, Kota, Kusuda, Hiromu et al. (2011): Crack growth in Westerly granite during a cyclic loading test. Engineering Geology, 117, 3-4, 189-197, https://doi.org/10.1016/j.enggeo.2010.10.017.

Cnudde, Veerle and Boone, Matthieu Nicolaas. (2013): Highresolution X-ray computed tomography in geosciences: A review of the current technology and applications. EarthScience Reviews, 123, 1-17, https://doi.org/10.1016/j.earscirev.2013.04.003.

Costin, LS and Holcomb, DJ. (1981): Time-dependent failure of rock under cyclic loading. Tectonophysics, 79, 3-4, 279296, https://doi.org/10.1016/0040-1951(81)90117-7.

Erarslan, N and Williams, DJ. (2012): Investigating the effect of cyclic loading on the indirect tensile strength of rocks. Rock mechanics and rock engineering, 45, 3, 327-340, https://doi.org/10.1007/s00603-011-0209-7.

Evans, David John and Chadwick, RA. (2009): Underground gas storage: Worldwide experiences and future development in the UK and Europe, Geological Society of London, 313, https://doi.org/10.1144/SP313.

Fuenkajorn, Kittitep and Phueakphum, Decho. (2010): Effects of cyclic loading on mechanical properties of Maha Sarakham salt. Engineering Geology, 112, 1-4, 43-52, https:// doi.org/10.1016/j.enggeo.2010.01.002.

Guo, Yintong, Yang, Chunhe, Wang, Lei, Xu, Feng. (2018): Effects of Cyclic Loading on the Mechanical Properties of Mature Bedding Shale. Advances in Civil Engineering, 2018, https://doi.org/10.1155/2018/8985973.

Hangx, Suzanne JT, Spiers, Christopher J, and Peach, Colin J. (2010): Mechanical behavior of anhydrite caprock and implications for $\mathrm{CO} 2$ sealing capacity. Journal of Geophysical Research: Solid Earth, 115, B7, https://doi.org/10. 1029/2009JB006954.

He, Mingming, Li, Ning, Chen, Yunsheng, Zhu, Caihui. (2016): Strength and fatigue properties of sandstone under dynamic cyclic loading. Shock and Vibration, 2016, https://doi.org/10.1155/2016/9458582.

Jalalifar, Hossein, Farrokhi, Mostafa, and Kariminasab, Saeed. (2021): Effect of cyclic loading on Anhydrite mechanical and petrophysical properties: an Iranian Underground Gas Storage Caprock. Journal of Oil, Gas and Petrochemical Technology, 8, 1, 15-22, https://doi.org/10.22034/JOGPT. 2021.239074.1077.

Jobli, A.F., Noor, M.J.M., Tawie, Rudy, Hampden A.Z., Julai N.N. (2017): Uniaxial compressive strength of Malaysian weathered granite due to cyclic loading. Journal of Engineering and Applied Sciences, 12, 14, 4298-4301.

Joskow, Paul L. (2013): Natural Gas: From Shortages to Abundance in the United States, American Economic Review, 103, 3, 338-343, https://doi.org/10.1257/aer.103.3.338.
Kou, Miaomiao, Liu, Xinrong, Tang, Shangding, Tang, Shangding, Wang, Yunteng (2019): 3-D X-ray computed tomography on failure characteristics of rock-like materials under coupled hydro-mechanical loading. Theoretical and Applied Fracture Mechanics, 104, 102396, https://doi. org/10.1016/j.tafmec.2019.102396.

Li, Zaoyuan, Sun, Jinfei, Luo, PingYa, Lin, Luan, Deng, Zhizhong, Gua, Xiaoyang (2017): Research on the law of mechanical damage-induced deformation of cement sheaths of a gas storage well. Journal of Natural Gas Science and Engineering, 43, 48-57, https://doi.org/10.1016/j. jngse.2017.03.026.

Liang, Weiguo, Zhang, Chuanda, Gao, Hongbo, Yang, Xiaoqin, $\mathrm{Xu}$, Suguo, Zhao, Yangsheng (2012): Experiments on mechanical properties of salt rocks under cyclic loading. Journal of Rock Mechanics and Geotechnical Engineering, 4, 1, 54-61, https://doi.org/10.3724/SP.J.1235.2012. 00054.

Liang, Yunpei, Li, Qingmiao, Gu, Yilei, Zou Quanle (2017): Mechanical and acoustic emission characteristics of rock: Effect of loading and unloading confining pressure at the postpeak stage. Journal of Natural Gas Science and Engineering, 44, 54-64, https://doi.org/10.1016/j.jngse.2017. 04.012.

Liu, Enlong and He, Siming. (2012): Effects of cyclic dynamic loading on the mechanical properties of intact rock samples under confining pressure conditions. Engineering Geology, 125, 81-91, https://doi.org/10.1016/j.enggeo. 2011.11.007.

Liu, Jianfeng, Xie, Heping, Hou, Zhengmeng, Yang, Chunhe,Chen, Liang (2014): Damage evolution of rock salt under cyclic loading in unixial tests. Acta Geotechnica, 9, 1, 153-160, https://doi.org/10.1007/s11440-0130236-5.

Malenda, MG, Frash, L, and Carey, JW. (2015): Uniaxial Compression Analysis and Microdeformation Characterization of Kevin Dome Anhydrite Caprock., AGU Fall Meeting, San Francisco, CA, Paper No. H53H -1763, 2015.

Mehrgini, Behzad, Memarian, Hossein, Dusseault, Maurice B et al. (2016): Geomechanical characteristics of common reservoir caprock in Iran (Gachsaran Formation), experimental and statistical analysis. Journal of Natural Gas Science and Engineering, 34, 898-907, https://doi.org/ 10.1016/j.jngse.2016.07.058.

Meng, Tao, Hu, Yaoqing, Fang, Ruiling, Kok, Jan, Fu, Qingnan, Feng, Gan (2015): Study of fracture toughness and weakening mechanisms in gypsum interlayers in corrosive environments. Journal of Natural Gas Science and Engineering, 26, 356-366, https://doi.org/10.1016/j.jngse.2015. 06.027 .

Meng, Tao, Zhang, DongHua, Hu, Yaoqing, Jianlin, Xie, Sufang, Song, Xiaoming, Li (2018): Study of the deformation characteristics and fracture criterion of the mixed mode fracture toughness of gypsum interlayers from Yunying salt cavern under a confining pressure. Journal of Natural Gas Science and Engineering, 58, 1-14, https:// doi.org/10.1016/j.jngse.2018.07.020. 
Mohammadabadi, Behzad Jafari, Shahriar, Kourosh, Jalalifar, Hossein, Ahangari, Kaveh (2021): An investigation on the effects of micro-parameters on the strength properties of rock. Rudarsko-geološko-naftni zbornik (The Mining-Geological-Petroleum Bulletin), 36, 1, 111-119, https:/doi. org/10.17794/rgn.2021.1.9.

Müller, WH, Schmid, SM, and Briegel, U. 1981. Deformation experiments on anhydrite rocks of different grain sizes: rheology and microfabric. Tectonophysics, 78, 1-4, 527-543.

Pouya, Ahmad, Zhu, Cheng, and Arson, Chloé. (2016): Micro-macro approach of salt viscous fatigue under cyclic loading. Mechanics of Materials, 93, 13-31, https://doi. org/10.1016/j.mechmat.2015.10.009.

Rao, MVMS and Ramana, YV. (1992): A study of progressive failure of rock under cyclic loading by ultrasonic and AE monitoring techniques. Rock Mechanics and Rock Engineering, 25, 4, 237-251.

Raza, Arshad, Gholami, Raoof, Sarmadivaleh, Mohammad, Tarom, Nathan, Rezaee, Reza, Bing, Chua Han, Nagarajan, Ramasamy, Hamid, Mohamed Ali, Elochukwu, Henry (2016): Integrity analysis of CO2 storage sites concerning geochemical-geomechanical interactions in saline aquifers. Journal of Natural Gas Science and Engineering, 36, 224-240, https://doi.org/10.1016/j.jngse.2016.10.016.

Reuter, M, Piller, WE, Harzhauser, M, Mandic, M, Berning, B, Rogl, F, Kroh, A, Aubry, M.P, Wielandt Schuster, U, Hamedani, A. (2009): The Oligo-/Miocene Qom Formation (Iran): evidence for an early Burdigalian restriction of the Tethyan Seaway and closure of its Iranian gateways. International Journal of Earth Sciences, 98, 3, 627-650, https://doi.org/10.1007/s00531-007-0269-9.

Robertson, Eugene C, Robie, Richard A, and Books, Kenneth G. (1958): Physical properties of salt, anhydrite and gypsum: preliminary report, United States Department of the Interior Geological Survey, 1-40, https://doi.org/10.3133/ tem1048.

Šancer, Jindřich, Štrejbar, Martin, and Maleňáková, Aneta. (2011): Effects of cyclic loading on the rheological properties of sandstones. Open Geosciences, 3, 2, 207-214, https://doi.org/10.2478/s13533-011-0020-8.

Schwerdtner, WM, Tou, JC-M, and Hertz, PB. (1965): Elastic properties of single crystals of anhydrite. Canadian Journal of Earth Sciences, 2, 6, 673-683, https://doi.org/10.1139/ e65-047.
Shalabi, Faisal I, Cording, Edward J, and Al-Hattamleh, Omar H. (2007): Estimation of rock engineering properties using hardness tests. Engineering Geology, 90, 3-4, 138-147, https://doi.org/10.1016/j.enggeo.2006.12.006.

Smith, Steven A, McLellan, Pat, Hawkes, Chris, Steadman, Edward N, Harju, John A (2009): Geomechanical testing and modeling of reservoir and cap rock integrity in an acid gas EOR/sequestration project, Zama, Alberta, Canada. Energy Procedia, 1, 1, 2169-2176, https://doi.org/10.1016/j. egypro.2009.01.282.

Streit, Jürgen E and Hillis, Richard R. (2004): Estimating fault stability and sustainable fluid pressures for underground storage of CO2 in porous rock. Energy, 29, 9-10, 14451456, https://doi.org/10.1016/j.energy.2004.03.078.

Taheri, Abbas, Hamzah, Noorfaizah, and Dai, Qien. (2017): Degradation and improvement of mechanical properties of rock under triaxial compressive cyclic loading. Japanese Geotechnical Society Special Publication, 5, 2, 71-78, http://doi.org/10.3208/jgssp.v05.017.

Trippetta, F, Collettini, C, Meredith, PG, Vinciguerra, S (2013): Evolution of the elastic moduli of seismogenic Triassic Evaporites subjected to cyclic stressing. Tectonophysics, 592, 67-79, https://doi.org/10.1016/j.tecto.2013. 02.011 .

Wang, Yasong, Ma, Linjian, Fan, Pengxian, Chen, Yan (2016): A fatigue damage model for rock salt considering the effects of loading frequency and amplitude. International Journal of Mining Science and Technology, 26, 5, 955958, https://doi.org/10.1016/j.ijmst.2016.05.054.

Yin, Shuai and Xie, Runcheng. (2019): Experimental analysis of dynamic and static mechanical properties of deep thick anhydrite cap rocks under high-stress conditions. Carbonates and Evaporites, 34, 3, 807-823.

Zhang, Yu, Chen, Yulong, Yu, Rangang, Hu, Liangqiang, Irfan, Muhammad (2017): Effect of loading rate on the felicity effect of three rock types. Rock Mechanics and Rock Engineering, 50, 6, 1673-1681, https://doi.org/10.1007/ s00603-017-1178-2.

Zulauf, G, Zulauf, J, Bornemann, O, Kihm, N, Peinl, M, Zanella, F (2009): Experimental deformation of a singlelayer anhydrite in halite matrix under bulk constriction. Part 1: Geometric and kinematic aspects. Journal of Structural Geology, 31, 4, 460-474, https://doi.org/10.1016/j. jsg.2009.01.013. 


\section{SAŽETAK}

\section{Procjena čvrstoće i petrofizičkih svojstava anhidritne krovine na temelju promjenjivih opterećenja i računalne tomografije}

Podzemno skladište plina smješteno u iscrpljenim ležištima utječe i na svojstva krovine. Sličnost između anhidrita Qom uzorkovanoga na površinskome izdanku te iz krhotina dobivenih s 2629 m dubine opisana je na temelju rezultata difrakcije x-zraka i skeniranja elektroničkim mikroskopom. Maksimalna jednoosna tlačna čvrstoća uzorka anhidrita mijenja se u uvjetima statičkih, promjenjivih, cikličkih opterećenja, pri čemu dolazi i do promjene petrofizičkih svojstava poput šupljikavosti i propusnosti, npr. tijekom 10, 20 i 30 ciklusa. Magnituda opterećenja bila je u rasponu od 30 do $43 \%$ maksimalne tlačne čvrstoće anhidrita, dok je intenzitet opterećenja kod cikličkih testova iznosio o,oo4 mm/s. Kod ispitivanih uzoraka zamijećeno je smanjenje maksimalne tlačne čvrstoće u rasponu od 3,5 do 23,9\% pri različitim uvjetima promjena opterećenja. Proučavanjem šupljikavosti i propusnosti uzoraka i snimki računalne tomografije vidljiv je porast broja pukotina u uzorku, pri čemu je uočeno da do stvaranja pukotina nije došlo uzduž cijeloga uzorka, kao što niti porastom šupljikavosti nije došlo do rasta propusnosti. Iako su uzorci bili izloženi cikličkim opterećenjima, propusnost uzoraka ostala je manja od $10^{-15} \mathrm{~m}^{2}$ (o,oo1 $\left.\mathrm{mD}\right)$. Proučavanjem promjene tlaka u vremenu uočen je veći pad tlaka zbog promjene propusnosti uzorka. Rezultati istraživanja upućuju na dobro podudaranje podataka dobivenih snimkama računalne tomografije i rezultata petrofizičkih ispitivanja.

\section{Ključne riječi:}

podzemno skladište plina, ciklička opterećenja, anhidrit, maksimalna tlačna čvrstoća, računalna tomografija

\section{Author's contribution}

Mostafa Farrokhi (1) (Ph.D. candidate, Petroleum Engineering) carried out the site visits, sample gathering, and laboratory testing. Hossein Jalalifar (2) (Professor, Rock Mechanics) attended weekly meetings, monitored test results, provided the testing apparatus, and supervised manuscript preparation. Saeed Karimi Nasab (3) (Assistant Professor, Engineering Geology) suggesting the required process, attended weekly reports, guided the testing procedure, and provided the proper testing apparatus. 